\title{
ECONOMIC AND MONETARY UNION IN THE ACCESSION COUNTRIES - POLITICAL AND ECONOMIC CONTEXTS
}

\author{
Maria DUNIN-WASOWICZ*
}

\begin{abstract}
:
The EU-25 will start operating on May 1, 2004. This paper reviews the position of the new Member States (NMS) in the Economic and Monetary Union (EMU) with respect to future adoption of euro. It argues that further integration in this area is much more about the deepening of the political integrity of the EU than about lowering transaction costs. However, a debate on the political and economic implications resulting from the adoption of euro by the NMS is full of unsolved issues. The central one is to define the possible scenario of the path to the euro. It implies actions on both sides: the NMS need to implement many economic reforms and enhance the political debate on the benefits of the euro adoption. The EU side must proceed with reforms, including the redefinition of the Stability and Growth Pact. The lack of reforms may hamper the political position of the EU.
\end{abstract}

Keywords: euro, EMU, accession countries, adoption of the euro, EMU criteria, public opinion

JEL Classification: F02, F15, G15

\begin{abstract}
"Europe cannot and it should not become only an economic affair; it needs a heart... political will remaining in service of common humanistic ideals" (Robert Schuman)
\end{abstract}

\section{Introduction}

A debate on the political and economic merits of the adoption of the euro in the new Member States has been overshadowed by their long preparations to join the

*) Graduate School of Economics - Higher School of Commerce and International Finance, Nowogrodzka 56, 00-695 Warsaw, Poland. 
European Union in May 20041). At the same time, many of newcomers are suffering from deep cuts in social expenditures in order to meet the Maastricht criteria in the coming future. Some of them struggle with the problem of how to speed up the economy, and some - with the embarrassing issue of extremely high unemployment. Thus, it is surprising that public opinion in these countries is not particularly against euro. On the contrary, it is still possible to recognise much enthusiasm in the group of "Ten" toward the common European currency (see Eurobarometer, 2002).

Obviously, the EMU and the euro cannot only be understood in economic and monetary terms alone. Such a remark was strongly perceived by old Member States as it has been in the case of Germany or France and in spite of the economic potential they represented. This consideration is also shared by the political elites of the accession countries. They recognise that joining the EMU and then adopting the euro are much more about the deepening of the political integrity of the EU than about lowering transaction costs. Article 4 of the 2003 Athens Accession Treaty which resulted from such an attitude towards the EMU - discloses that every newcomers will participate in the EMU as a Member State with derogation from the adoption of the euro. This provision marks the problems, which are expected to come while negotiating the timing for replacing a national currency by the euro.

Let's have a brief look at the general situation in the Central European Countries (CEC). An adoption of the euro by Poland is a long lasting and well-known political target in this country. Some economists were asking for a so-called "euroisation" even before accession to the EU. The prospect of joining the euro in 2007 is still officially supported by the Finance Ministry. Leszek Balcerowicz, chairman of the National Bank of Poland, underlines that the euro is important for Poland. In his mind "the EU membership gives the opportunity to catch-up, but the actual economic outcomes depends on the quality of domestic policy" (see Balcerowicz, 2003). Witold Orłowski, Chief Economic Adviser to the President of Poland, indicated that 2010 would be a more appropriate horizon for the euro in Poland. There is still a lot of work to be done in Poland, especially in terms of reforms of public finance. The general attitude towards the euro in the Czech Republic is much the same as it is in Poland. Nobody knows, however, how the situation will evolve with Václav Klaus, elected as president in February 2003. The government headed by Vladimír Špidla, since June 2002, declared that the Czech Republic would be ready to adopt the euro in 2010. Hungarian politicians, not only economists, are concerned both about the economic growth and about the schedule for the adoption of the euro. At its meeting on 16 July 2003, the Hungarian government set the first of January 2008 as a target day for adopting the euro in Hungary. Moreover, the government also indicated that it is ready to initiate Hungary's earliest possible entry into the Exchange Rate Mechanism II (ERM II). In the remaining five accession countries, the situation is less clear as that of Hungary, though Estonia and Lithuania, which have currency boards backed by the euro (see Table 1), are keen for a fast introduction of the euro. Cyprus also officially declares that it is ready to use the euro two years after the accession date, that is, in 2006.

All in all, the new members would like to arrange a date to introduce the euro during the years $2006-2010$. This, however, is questioned by some EU analysts. They argue that the biggest countries of Central Europe - Poland, Hungary and the Czech Republic - having secured their places in the EU, are more inclined to delay

1) Accession countries, the so-called Laeken Group, consist of ten countries that signed the Treaty in Athens on April 16, 2003: Cyprus, the Czech Republic, Estonia, Hungary, Latvia, Lithuania, Malta, Poland, Slovakia and Slovenia. 
Table 1

Explicit Goals for EMU Participation and Subsequent Adoption of the Euro

\begin{tabular}{|c|c|c|c|}
\hline & Exchange rate regime & Euro target date & ERM II participation \\
\hline Cyprus & $\begin{array}{l}\text { Peg to euro with wide } \\
\text { band and soft inner } \\
\text { band }\end{array}$ & $\begin{array}{l}\text { As early as possible } \\
\text { after EU accession }\end{array}$ & $\begin{array}{l}\text { Upon accession (implied } \\
\text { by euro target date and } \\
\text { current regime) }\end{array}$ \\
\hline Czech Rep. & Managed float & Not stated in PEP & $\begin{array}{l}\text { Standard fluctuation } \\
\text { bands }\end{array}$ \\
\hline Estonia & $\begin{array}{l}\text { Currency board } \\
\text { arrangement (CBA) with } \\
\text { euro }\end{array}$ & Not stated in PEP & Not stated in PEP \\
\hline Hungary & $\begin{array}{l}\text { Peg to euro with wide } \\
\text { band }(15 \%)\end{array}$ & $\begin{array}{l}\text { To be decided after EU } \\
\text { accession (PEP aims to } \\
\text { meet convergence } \\
\text { criteria in 2005) }\end{array}$ & After accession \\
\hline Latvia & Peg to SDR & Not stated in PEP & $\begin{array}{l}\text { As of accession or at a } \\
\text { later stage }\end{array}$ \\
\hline Lithuania & $\begin{array}{l}\text { CBA with euro } \\
\text { (since } 2 \text { Feb. 2002) }\end{array}$ & Not stated in PEP & Not stated in PEP \\
\hline Malta & $\begin{array}{l}\text { Peg to trade weighted } \\
\text { basket }\end{array}$ & Not stated in PEP & $\begin{array}{l}\text { As soon as possible after } \\
\text { EU accession }\end{array}$ \\
\hline Poland & Float & $\begin{array}{l}\text { Policy goal to meet } \\
\text { convergence criteria in } \\
2005 \text { (addendum to } \\
\text { PEP) }\end{array}$ & After accession \\
\hline Slovakia & $\begin{array}{l}\text { Managed float with euro } \\
\text { as reference }\end{array}$ & $\begin{array}{l}\text { As early as possible } \\
\text { after EU }\end{array}$ & Upon accession \\
\hline Slovenia & $\begin{array}{l}\text { Managed float with euro } \\
\text { as reference }\end{array}$ & $\begin{array}{l}\text { As early as possible } \\
\text { after EU }\end{array}$ & Not stated in PEP \\
\hline
\end{tabular}

Note: PEP = Pre-accession Economic Programme, which was submitted to the EU by August 15, 2003.

Source: Evaluation of the 2001 Pre-accession Economic Programmes of Candidate Countries. The EC, January 2002.

their entry into the euro until as late as 2010 for economic reasons. At the same time and also for economic reasons, some of these experts would like to see a longer delay, before the new Member States enter into the eurozone. They assert that attempts to comply with the criteria in a relatively short period would destabilise the NMS's economies. As such, it may result in a real divergence instead of a real convergence. This contrasts with other opinions represented amongst other by Balcerowicz, who considers that "the accession countries are highly integrated with the EU economy, hence costs associated with giving up an independent monetary policy and flexible exchange rate would not be significant". This brief review suggests a concluding remark that the "operation EU enlargement" is going well so far. How will the "eurozone expansion" work? There are no doubts that the introduction of the euro is a radical moment in the European continent's history. This contrasts with the 
growing fear raised amongst the smaller countries ${ }^{2}$ (see Eurobarometer, 2003) that the accepted rules of the EMU do not prevent against developing an intergovernmental Europe run by the big two or three dominant countries. It stands up in parallel with the concern across the EU that the eurozone has no rules or common guidelines for how fiscal policy is to be pursued by the Member States.

Therefore, the analytical perspective of this essay departs in two ways. First, I argue that there is a need to act wisely with regard to possible discussions on the concept of statehood and sovereignty in the new Member States. EMU members abandoned already part of their traditionally perceived sovereignty to the European Central Bank (ECB). They cannot influence its policy, although their National Banks' Governors participate in its decision-making process. In other words, it will be important to inform the public of the newcomers that, for a proper functioning of the $E U$, it is essential that the ECB dispose of the right to decide on interest rate. The public has to be assured that the country's interest will not be undermined by the ECB, which has to meet the requirement of the interest rate policy. Second, technical issues will also be relevant for that debate. The new Members have to be really prepared to meet the economic requirements, which is now only partially the case. The so-called "technicalities" refer also to decisions on reforms that have to be undertaken in the sector of public finance. In sum, it is presently difficult to judge, which arguments would prevail in an open debate. The only obvious political position of the NMS toward the adoption of the EMU principles was formulated in their position papers during accession talks (see Table 2). Preliminary decisions with regard to exchange rate strategy and participation in the ERM II will be needed soon.

Table 2

Negotiations on the EMU within the Accession Talks

\begin{tabular}{|l|l|l|}
\hline Country & Chapter opened & Chapter closed (provisionally) $)^{1}$ \\
\hline Cyprus & First half of 1999 & End of 1999 \\
\hline Czech Republic & First half of 1999 & End of 1999 \\
\hline Estonia & First half of 1999 & End of 1999 \\
\hline Hungary & First half of 1999 & End of 1999 \\
\hline Latvia & Second half of 2000 & End of 2000 \\
\hline Lithuania & First half of 2001 & First half of 2001 \\
\hline Malta & Second half of 2000 & End of 2000 \\
\hline Poland & First half of 1999 & End of 1999 \\
\hline Slovakia & First half of 2001 & First half of 2001 \\
\hline Slovenia & First half of 1999 & End of 1999 \\
\hline
\end{tabular}

Note: There are no transitional arrangements in this chapter.

1) The final closure of all chapters took place on December 2002. The accession talks were undertaken under the rule "nothing is agreed until everything is agreed".

2) Note, that according to the latest poll of the Eurobarometer 2003, the support of small and medium countries for the euro has fallen last year ranging from minus 1 per cent (Denmark) by minus 6 per cent (Greece, Portugal). Surprisingly, the Swedish sentiment for the euro becomes stabile, keeping the level of 43 per cent. 


\section{The Puzzle of the EMU: Fulfilling the Copenha- gen Criteria in Accession Countries and the Po- litical Must for the Euro}

Since 1989, the vehicle of European integration was driven by flawless political assumptions stating that, on the one hand, an integrated Europe is needed more than ever and, on the other, that the economic interests of both sides should be secured. Therefore, the signing of the Maastricht Treaty, establishing the EMU as a primary goal for the EU before the enlargement and inclusion of the CECs, was not welcomed with much pleasure by those countries. The Polish elite or the Hungarian one voiced one of the strongest views against the assumed sequence of the EU development. It was clear then, that the ups and downs of the single currency project were observed with mixed emotions. With fear: Would the Union, in the framework of the EMU and despite the coming enlargement, renew the political divisions of Europe, set up after World War II? With curiosity: Would the public once involved in such a difficult economic "project" support the EU political elite's? Once the accession negotiations started, attitudes towards the EMU turned to the another idea: participating to the EMU and the euro were possible, though hard to achieve.

Disputes in the novices about the timing of the adoption of the euro will not, however, mirror the traditional discussion that emerged in the old Member States for three reasons at least.

Firstly, the EU partly excluded such a discussion by creating the so-called "third Copenhagen criterion", blocking de facto a possibility for the "Ten" to ask for an opting-out clause of the EMU and of the euro. Some analysts are more straightforward, saying that, "for all the accession countries the introduction of the euro will be - on the contrary to present Member States - compulsory" (see Temprano-Arroyo, Feldman, 1998).

Secondly, within the last ten years the EU not only evolved economically, but above all - politically. Therefore, again, different questions arise about the political future of an enlarged EU other than those considered as important several years ago. Last, but not least, both the political and economic convictions about the importance of strictly observing the Maastricht criteria are slowly but steadily fading away amongst the old Member States. Moreover, in the near future, some slackening or stretching of the rules of the Stability and Growth Pact is already anticipated by the old Member States (see Buti, Eijffinger, Franco, 2003). This more so after the decision of the ECOFIN Council ${ }^{3)}$ to suspend the excessive deficit procedure against France and Germany. Consequently, any decision in this matter may have an impact on the negotiations regarding the NMS schedule for adopting the euro. The "negotiations after negotiations" will add a new dimension to that convergence debate. In sum, one could argue that the too-weakly-prepared-to-matter syndrome would not play such a negative role as it is supposed to do.

The too-weakly-prepared-to-matter syndrome. This syndrome appeared at the beginning of the 1990s, just during the negotiations for the Association Treaties. It was the first time that the CECs were warned that a subversion of Communism would not lead them directly to membership in the EU. Consequently, in 1993, the EU Council created a set of conditions (the so-called Copenhagen criteria) as a requisite for their future membership in the Union. The first criterion (see Copenha-

3) The ECOFIN Council took place on November 25, 2003. 
gen Council, 1993) entailed that the applicant countries had to create market economies. The second pressed to ensure the stability of institutions guaranteeing democracy, the rule of law, the protection of human rights and the respect for minorities. Finally, the third one indicated that applicant countries had to fulfil the obligations of membership, "including adherence to the aims of the economic, monetary and political environment as one of the conditions". The political commentary on this last criterion explained that the accession countries (AC) did not have any formal possibility of joining the EU without the adoption of the EMU and the euro.

Enlargement became an accepted part of the Union's future with the decisions of the Madrid Council in December 1995. During this summit, another provision was set forth saying that "the creation of a stable economic and monetary environment" marked the way for the "gradual and harmonious integration of the candidate countries into the EU" (see Madrid Council's, conclusions). And again, the forces of political economy at work are straightforward. Both the readiness to apply the jungle of the "acquis communautaire" (ibidem, 1993) and a real economic convergence will be taken for granted in respect to the acceptance of the new EMU members. Not earlier, however. This is the too-weakly-prepared-to-matter syndrome. The positive effect of such a syndrome may be that the ACs were obliged to follow the aim of the EMU and to develop their capacity to correct macroeconomic distortions even though they were not obliged to meet the Maastricht criteria at the time of accession. It was agreed by the EU that these criteria should not be regarded as a short-term objective, "but rather a goal for the medium to long run". It means, however, that the EU may endlessly pigeonhole the adoption of the euro. This is a negative effect of the syndrome, which is not welcomed at all by the monetary authorities in some countries. Grzegorz Wójtowicz, member of the Polish Monetary Policy Council, underlined that "the possibility of being included quickly in the eurozone may create a kind of a dopping for the economy to stiffen it and fulfil the EMU criteria".

Economic and political attitudes. However, there is a bumpy road to meeting the convergence criteria: all the NMS work at length to restructure their economies. This necessity also reflects the EU's influence on creating a stability-oriented reputation of the new policy regime, not only in the euro area, but also in coming members of the EMU. Despite that, new Member States have in mind, as the "Agenda 2000" indicates, that they should maintain "...key points of reference for stabilityoriented macroeconomic policies and must in time be fulfilled by the member states on a permanent basis" (see Berlin Council, 2000). The framework of such policies with regard to the co-ordination of economic, fiscal, monetary, and exchange rate policies, had been defined in each of the negotiation position papers. It was underlined also there that the Central Banks' independence of governments and the absence of recourse to central bank credits in financing the budget deficits were also required. Finally, it was pointed out that the applicant countries should regard their monetary and exchange policy as a matter of common interest. Both negotiating parties understood the adoption of the euro as the ultimate phase.

Defining the principles of mutual and permanent economic co-operation had marked the first step of the CEC toward the EMU, well before the accession talks had started. Such documents, entitled: "Joint Assessment of Medium Term Economic Priorities", were prepared by the those countries in 1997. The subsequent step in accordance with establishing the framework of exchange rate strategies had been undertaken by the Union during the meeting of the Economic and Finance Ministers (ECOFIN) in November 2000. By setting "three successive stages in the transition process towards adoption of the euro, namely, the pre-accession stage, the stage following accession and the adoption of the euro" (ibidem), the Council excluded the possibility of applying unilateral "euroisation". It pointed out that, during the pre- 
Table 3

Toward the Maastricht Criteria and Economic Convergence

\begin{tabular}{|c|c|c|c|c|c|c|c|c|c|c|c|c|c|c|}
\hline Criterion & \multicolumn{2}{|c|}{ Inflation } & \multicolumn{2}{|c|}{ Interest $10 \mathrm{Y}$} & \multicolumn{2}{|c|}{ FX rate } & \multicolumn{2}{|c|}{ Deficit } & \multicolumn{2}{|c|}{ Debt } & \multicolumn{2}{|c|}{ GDP } & \multicolumn{2}{|c|}{ Unemployed } \\
\hline & '01 & '02 & 01 & '02 & 01 & '02 & '01 & '02 & '01 & '02 & 01 & '02 & '01 & '02 \\
\hline $\begin{array}{l}\text { Reference } \\
\text { value }\end{array}$ & 3.3 & 3.0 & 7.4 & 5.8 & \multicolumn{2}{|c|}{$\begin{array}{l}\text { Deviation } \\
\pm 15 \% 1)\end{array}$} & \multicolumn{2}{|c|}{$\begin{array}{r}-3.0 \% \\
\text { of GDP }\end{array}$} & \multicolumn{2}{|c|}{$\begin{array}{l}60.00 \% \\
\text { of GDP }\end{array}$} & \multicolumn{2}{|c|}{ Growth \% } & \multicolumn{2}{|c|}{$\begin{array}{l}\% \text { of active } \\
\text { population }\end{array}$} \\
\hline Cyprus & n.a & n.a & n.a & n.a & n.a. & n.a. & n.a. & n.a. & 54.6 & 55.9 & 4.0 & 2.8 & 4.0 & 3.3 \\
\hline Czech Rep. & 4.7 & 2.0 & 5.6 & 4.0 & -5.5 & -5.1 & -5.5 & -6.4 & 23.7 & 25.6 & 3.3 & 3.0 & 8.0 & 7.3 \\
\hline Estonia & 5.8 & 4.3 & 4.7 & 3.6 & -1.2 & -1.6 & 0.2 & -0.2 & 4.8 & 4.4 & 5.0 & 4.3 & 12.4 & 11.5 \\
\hline Hungary & 8.5 & 5.5 & 7.0 & 6.3 & -4.4 & -6.1 & -4.1 & -5.7 & 53.1 & 52.9 & 3.8 & 4.0 & 5.7 & 5.5 \\
\hline Latvia & 2.5 & 2.6 & 10.7 & 7.8 & 2.6 & -11.1 & -1.6 & -1.8 & 16.0 & 16.8 & 7.7 & 5.0 & 13.1 & 12.5 \\
\hline Lithuania & 1.3 & 1.2 & 7.9 & 6.4 & 8.6 & -5.0 & -1.9 & -1.9 & 23.1 & 23.6 & 5.9 & 4.7 & 16.5 & 16.4 \\
\hline Malta & n.d. & 2.5 & n.d. & n.d. & n.d. & n.d. & -7.0 & -5.2 & 65.7 & 64.9 & -0.8 & 3.3 & 6.5 & 5.5 \\
\hline Poland & 5.5 & 2.5 & 8.3 & 5.4 & -8.2 & -15.0 & -3.9 & -4.1 & 39.3 & 43.3 & 1.1 & 1.0 & 18.4 & 19.2 \\
\hline Slovakia & 7.3 & 4.0 & 7.8 & 7.4 & -1.8 & -4.8 & -5.6 & -4.6 & 44.1 & 39.3 & 3.3 & 3.6 & 19.4 & 18.9 \\
\hline Slovenia & 8.5 & 7.0 & n.a. & 8.1 & -7.4 & -5.8 & -2.5 & -1.8 & 27.5 & 27.9 & 3.0 & 3.3 & 5.7 & 6.4 \\
\hline
\end{tabular}

1) Average rate of exchange of the last 3 years against euro.

Table 4

Consumer Price Index (in \% on preceding year)

\begin{tabular}{|c|c|c|c|c|c|c|c|c|}
\hline & 1997 & 1998 & 1999 & 2000 & 2001 & 2002 & 2003 & 2004 \\
\hline Cyprus & 3.3 & 2.3 & 1.1 & 4.9 & 2.0 & 2.8 & 4.3 & 2.1 \\
\hline Estonia & 9.3 & 8.8 & 3.1 & 3.9 & 5.8 & 3.6 & 1.6 & 3.9 \\
\hline Hungary & 18.5 & 14.2 & 10.0 & 10.0 & 9.2 & 5.2 & 4.6 & 6.1 \\
\hline Latvia & 8.1 & 4.3 & 2.1 & 2.6 & 2.5 & 2.0 & 2.5 & 3.0 \\
\hline Lithuania & 8.8 & 5.0 & 0.7 & 0.9 & 1.3 & 0.4 & -0.9 & 2.3 \\
\hline Malta & 6.4 & 3.7 & 2.3 & 3.0 & 2.9 & 2.2 & 1.3 & 1.8 \\
\hline Poland & 15.0 & 11.8 & 7.2 & 10.1 & 5.5 & 1.9 & 0.7 & 1.9 \\
\hline Czech Rep. & 8.0 & 9.7 & 1.8 & 3.9 & 4.7 & 1.4 & 0.0 & 3.3 \\
\hline Slovakia & 6.0 & 6.7 & 10.8 & 12.3 & 7.3 & 3.3 & 8.5 & 8.2 \\
\hline Slovenia & 8.3 & 7.9 & 6.1 & 8.9 & 8.5 & 7.5 & 5.9 & 5.2 \\
\hline Average AC10 & 12.5 & 10.5 & 6.3 & 8.4 & 5.9 & 2.7 & 2.3 & 3.7 \\
\hline $\begin{array}{l}\text { Average EU15 } \\
\text { Average EUR12 }\end{array}$ & $\begin{array}{l}1.8 \\
1.6\end{array}$ & $\begin{array}{l}1.9 \\
1.7\end{array}$ & $\begin{array}{l}1.4 \\
1.1\end{array}$ & $\begin{array}{l}1.5 \\
1.4\end{array}$ & $\begin{array}{l}2.4 \\
2.4\end{array}$ & $\begin{array}{l}2.5 \\
2.4\end{array}$ & $\begin{array}{l}2.0 \\
2.1\end{array}$ & $\begin{array}{l}1.9 \\
2.0\end{array}$ \\
\hline $\begin{array}{l}\text { Ratio AC10 / } \\
\text { / EU15 (in \%) }\end{array}$ & 696.0 & 552.0 & 447.8 & 559.4 & 243.8 & 108.7 & 115.0 & 194.7 \\
\hline $\begin{array}{l}\text { Ratio AC10 / } \\
\text { / EUR12 (in \%) }\end{array}$ & 783.0 & 617.0 & 569.9 & 599.3 & 243.8 & 113.2 & 109.5 & 185.0 \\
\hline
\end{tabular}


accession stage, however, the candidate countries may open a broad economic policy dialogue, including exchange rate strategies, in order to assist countries in the formulation of their economic accession strategies. This dialogue is also based on an annual examination of the Pre-accession Economic Programmes, which the ACs started to review during the first "EC forum", which has taken place in 2001.

A glance at the present performance with respect to the Maastricht criteria shows that the NMS will struggle with a number of difficulties (see Table 3 and 4). Inflation is still the Achilles heel of four of the ten acceding countries where it exceeded in 2002 and will exceed in 2003 the reference value of $3.0 \%$. In this respect, Poland made a considerable progress diminishing its inflation from 5.5 in 2001 to 1.9 in 2002 and 0.7 per cent in 2003 (see European Commission, November 2003). By end-year, consumer price inflation for the "Ten" should be well below 3 per cent, but could swing up again in 2004 (see ibidem, 2003). Further efforts have to be undertaken by Estonia, Hungary, Slovenia and Slovakia. On the other hand, Lithuania has registered a dangerously low inflation rate of $0.4 \%$ in 2002 and an expected $-0.9 \%$ in 2003. An acceleration of inflation in 2004 to $3.7 \%$ and then a slight decrease in 2005 to $3.3 \%$ are, however, expected for the whole group of "Ten". Fiscal deficits represent another serious issue. The three largest AC economies - Poland, the Czech Republic and Hungary - are troubled by high budget deficits that ballooned in 2002. According to the EBRD Transition Report (2003), extending budget deficits could delay the adoption of the euro for years in Eastern European countries. The report recommends that Poland "urgently" needs to crack down on spending. Indeed, Poland has to reduce a deficit that grew to $6.7 \%$ of the GDP last year. The case of Czech Republic, Slovakia, and Hungary, according to the EBRD is even worse: they won't get their deficits under the Maastricht limit this year. Simultaneously the EBRD notices that East European countries are making good progress in the transition to capitalism and enjoy growing economies. That's a result of rising trade and also of more government spending - much of it triggered by having "to revamp everything from garbage pickup to meat inspection to meet the EU's 80,000 pages of regulations", as put by the bank. But such spending - along with politically popular money for social benefits and job-preserving subsidies for industries - mean that these countries are still and will remain over the limit of $3 \%$ of GDP for budget deficits.

For the moment the general government debt, which with a level of $38.1 \%$ of the GDP well below the reference limit of $60 \%$, is a less troublesome problem.

Graph 1

Economic Co-operation with Candidate Countries Aiming at Adoption of the Euro

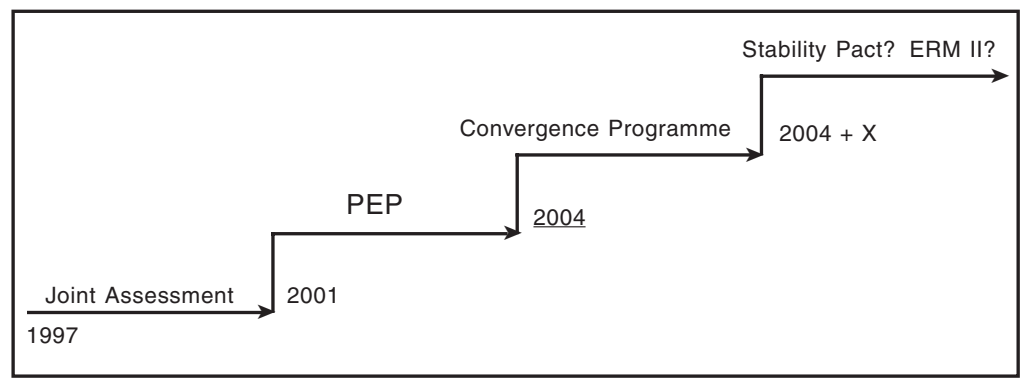

Source: On the basis of Directorate General EcFin documents, European Commission. 
However, implementing the Stability and Growth Pact (SGP) would be a serious challenge since it rests upon public finance reforms, which have still to take place, mainly in Poland, the Czech Republic and Hungary. ${ }^{4)}$ This may cause difficulties with consolidating the exchange rate regimes. For some countries, such as Estonia, which has a currency board backed by the euro, a quick transition may make sense. For others, the Exchange Rate Mechanism II (ERM II) may work as an invitation for speculative attacks, as happened in the EU during the crisis of the European Monetary System in 1992/1993 - especially if market operators believe that the parity grid is not sustainable.

Those countries, despite adverse external factors, reached a higher consolidated $2.4 \%$ GDP growth in 2002 against $1.1 \%$ for the EU-15. Latvia and Lithuania's growth were the highest with rates reaching respectively $5.0 \%$ and $4.7 \%$. In this respect, the previous year (i.e. 2002) was more difficult for Poland and the Czech Republic, where the growth was $1.1 \%$ and $0.8 \%$, respectively. Current data (see EC, 2003) are more optimistic indicating that Poland should achieve a growth of $3.3 \%$ of GDP this year, the Czech Republic $2.2 \%$ and Hungary $2.9 \%$. In general however, the quick development path will be difficult to roll on without a reinforcement of the macroeconomic stabilization environment. It will be particularly arduous for those willing to adopt the euro as soon as possible. More specifically, they will face the dilemma of either implementing restrictive polices to push inflation down or to accept a delay for adopting the euro. Slower economic growth would have a negative impact on the labour market, whilst unemployment rates are significantly above the EU average. Moreover, the persistence of high unemployment, which exceeds $18 \%$ in Poland and Slovakia, will be difficult to square with fiscal consolidation.

Table 5

GDP at Constant Prices, Mean for 10 Candidate Countries

\begin{tabular}{|c|c|c|c|c|c|}
\hline & $\%$ GDP 2002 & 2001 & 2002 & 2003 & 2004 \\
\hline & & \multicolumn{4}{|c|}{ Annual percentage change (\%) } \\
\hline Private consumption & 62.7 & 3.2 & 4.4 & 4.5 & 3.5 \\
\hline Government consumption & 17.9 & 2.7 & 2.4 & 2.3 & 1.3 \\
\hline Total investment & 21.9 & -1.7 & -0.6 & 2.4 & 6.6 \\
\hline Final demand & 149.3 & 1.0 & 2.6 & 3.3 & 3.9 \\
\hline Exports goods and services & 44.6 & 9.2 & 4.5 & 6.2 & 7.0 \\
\hline Imports goods and services & 49.3 & 5.9 & 4.7 & 6.4 & 7.2 \\
\hline Gross domestic product & 100.00 & 2.4 & 2.3 & 3.1 & 3.8 \\
\hline \multirow{4}{*}{\multicolumn{2}{|c|}{$\begin{array}{l}\text { Internal demand without stocks } \\
\text { Stock building } \\
\text { Exports net }\end{array}$}} & \multicolumn{4}{|c|}{ Contributions to GDP growth } \\
\hline & & 1.9 & 2.9 & 3.7 & 3.9 \\
\hline & & -0.9 & -0.1 & -0.2 & 0.1 \\
\hline & & 1.4 & -0.4 & -0.4 & -0.4 \\
\hline
\end{tabular}

Source: European Economy, Autumn 2003; Economic Forecasts No. 5/2003, November 2003.

4) It should be noticed that Spain and Ireland were partly able to achieve and maintain a budget equilibrium thanks to the large inflow of EC cohesion and structural funds, which amounts were largely superior to what the NMS can expect. 
The euro is, however, not only about economics; it is about politics as well. This is why the introduction of the single currency on January 1, 2002 was almost welcomed as a military victory by the European institutions and some governments of the EU. However, this victory is going to be imperfect. From the 1st of May 2004, the EU will be divided into three groups of countries with regard to the euro:

- those who wanted the euro and have it,

- those who may choose to have it or not, and

- those who want it, but have to remain outside, unless they ensure compliance with the Maastricht convergence criteria.

This state of fact forms a real split within the EU that sanctions the existence of the three euro-groups: the eurozone group; the "eurosceptic" group (UK, Denmark and Sweden); and, last but not least, the group of "Ten" new Member States.

From a legal point of view, the ACs would be in the same category as Sweden at present. It means, that up to the December 1997 decision of the Riksdag (The Swedish parliament), Sweden keeps "the door open for a later Swedish participation in the monetary union" (see Gottfries, 2002). For two reasons in general. As Swedes are used to say, they are better equipped to enter the monetary union thanks to the improvement of the Swedish economy as they are in a better position for remedying to any imbalances that may occur. Thus, Sweden prefers pursuing a floating exchange rate policy that offers a better business environment than it was the case in the previous 20 years of fixed exchange rate.

Politically, the situation is much more complex. First, no candidate country was allowed to ask for an opt-out clause, as did Great Britain (it is not clear when the entry of the UK into the euro area will be determined) and Denmark. Secondly, it seems that newcomers do not want to live as long as Sweden with the door opened for the euro. Obviously, the NMS are prepared to wait for the euro. But, they accepted the condition of departing from the adoption of euro, by bearing in mind that the waiting period for the single currency would not be too long. It seems that at present their political hopes have failed or, at least that they are in deep uncertainty. The representatives of the EC delivered various statements on this issue. The EC commissioner Pedro Solbes (2003) warned against premature attempts at EMU participation, saying that "countries (would) lose their exchange rate flexibility, while the process of structural change, catching up and fiscal consolidation is not yet finished". He rigidly suggests that the currencies' floating band during the minimum 2-years period of participation of the NMS countries in the ERM II may be set on more restrictive conditions than bilateral band of 15 per cent.

It also shows that the "too early for the euro" approach drawn around the European institutions already (...or for the time being) won the timetable battle. Moreover, the EU may want to see the present euro free riders, namely the UK, Denmark and Sweden, joining the euro area first (see The Euro at 25, 2003).

There are two important factors to considering such an event: first, the traditional EU political understanding of the "west" of Europe and, second, the level of economical preparedness of those countries to enter the eurozone. The NMS have seemingly to wait for the second round of "monetary" enlargement focusing on fulfilling the convergence criteria. The question is "for how long" bearing in mind the quite strong resistance of the society - up to now at least - against the euro in the three countries mentioned above. From this point of view the positive result of the Swedish referendum on the adoption of the euro could have been important. It was not however. Results of public opinions polls that were undertaken before the D-day did not indicate that Swedish people were decisively in favour of the euro. The referendum took place on September 14, 2003 and its outcome was negative: 56.2 per cent of Swedes did not vote in favour of swapping the crown for the euro. Therefore Sweden 
is not expected to adopt the single currency, as it was assumed, on January 1, 2006. In this case, a strategy of the enlargement of eurozone - for example in 2007 - remains "a black hole". Or, we might say that more cards are in the hands of the "Ten", if they prove to be able to fulfil the Maastricht criteria in the relatively near future.

Another set of problems is created by the results of the 7-years performance of the Stability and Growth Pact (1997). As many analysts notice, SGP neither warrants stability nor growth (see Barysch, 2003). It started to work in countries that applied an appropriate fiscal policy. Others, particularly Germany, France and Italy, not only failed to stick to their fiscal priorities, which resulted in problems of following the rules of the Pact, but succeeded in suspending the application of the rules (see supra). Clearly, the EU has to rethink some rules of the Pact; otherwise George Soros will achieve triumph, since he predicted in 1995 that the principle of permanent convergence is not a panacea for EU hindrances. Assuming that Europe needs more flexible fiscal rules, a question can be raised: what would be the real criteria that the NMS should fulfil for picking up the euro? Or, what will be the impact of eventual new rules on the sustainability of public finances? These are crucial queries that might influence the political discussion about the timing of the adoption of the euro by CEC.

Finally, subsequent tensions could arise from disputes over the reform of the European Central Bank. With accession to the EU, every chairman of the National Central Banks will receive a chair at the General Council that does not, however, have any say on the monetary policy, this being the target-job of the Governing Council (18 members). Assuming that the "Ten" will some day join the euro area, the Governing Council could have up to 28 members or, given afore-mentioned "first" enlargement, up to 31 members. Will the recomposed Governing Council still be able to govern bearing in mind that the voting rights of any member should be respected with regard to the Treaty on European Union (TEU)? A strategic response to the issue will help avoiding the ill-fated effect that the Union might be perceived as a two-speed construction formed by first and second class members, in other words - those holding the power over the monetary policy and those having to fall in line.

\section{The Euro Coins Jewel-case - a Case of Politics}

Despite all the odds with the essence of the EMU, the desire expressed by public opinion (see Eurobarometer, 2002) to replace national currencies by the euro remains quite high in all CEC. Simultaneously, membership in the EU was questioned in some of them during the last few years in the midst of difficult accession talks. On the brink of EU membership, $67 \%$ of the respondents in the "Ten" were in favour of a changeover to the euro, whereas only $52 \%$ regarded their country's EU membership as "a good thing".

This, however, underscored a general paradox: the euro, which cannot be adopted without EU membership, was most probably understood as a simple means of exchange rather than as the outcome of a policy which had no precedence in the political, economic and social history of the European continent. The outcomes of the membership referenda disclose that societies have started to think about the path to the euro in a more political way as well. Nevertheless, the hypothetical explanation for the ambiguity mentioned above would result from the relatively short time during which national currencies played any monetary role in post-communist countries. In most cases, a long-lasting positive sentiment toward the USD or the DEM was observed. They both represented, let us say, external economic strength and stability. The euro, being a consequence of political will and the merits of a European currency union - one that reflects the economic policy-mix and global 
demands - also represents the opportunity for "importing" good practices of economic policy and reasonable politics as such. At what price? A brief overview of the situation in three of the main countries of the region, Poland, the Czech Republic and Hungary, may provide an answer.

The euro and Polish perceptions of the European order. Polish attitudes towards the euro have essentially been linked to its long-lasting understanding of the process of European integration. For Poles, membership in the EU represents a real overthrow of Communism. The Pope, by offering a jewel-case of euro coins as a souvenir ${ }^{5}$ to the Polish Prime Minister Leszek Miller, most likely indicated to him and to all Poles that Poland being an important and traditional part of the European continent for more than a thousand years had two goals: membership in the EU and subsequent adoption of the single European currency. Anyway, it was an important signal for that part of public opinion confused by the right-wing political party (called "League of the Polish Families") or by some representatives of the church and their not-very-positive attitudes toward membership in the EU, which will permit to use the euro also.

Although there is a common understanding amongst the political parties that a free Poland cannot retain its traditional zloty in a globalising world, politicians do not speak openly about their attitudes toward the euro. It seems that they prefer to follow a prudent governmental approach demanding, amongst other thing, a permission from the Central Bank to introduce some creative accounting that would help "reduce" the fiscal deficit - showing that passing to the euro will not happen overnight. While politicians keep silent or try to shrink the level of independence of the Central Bank, the experts exchange their views. The economists drawn around the Chairman of the National Central Bank, Leszek Balcerowicz, mostly state that, "....in Polish circumstances the exchange rate becomes a source of economic deviations than the means of shock absorption" (see Rostowski, 2003). Some of them called strongly for so-called "euroisation". Experts who follow the line of the Ministry of Finance argue that Poland may adopt euro in 2008 under the condition, however, that the public finances sector will be stabilised. It is worrisome, however, that at the same time, the ministry of finance has prepared the draft of budget for 2004 which discloses that the stabilization of public finance sector may not start in the year to come.

Despite that fundamental difference referring to the methods on how and when the reform of fiscal policy should be introduced, both sides are convinced that deep structural reforms of public finance have to be undertaken in Poland. Both are also convinced that such a reform will create substantial difficulties for society. The lack of reforms will not improve the situation at all. The new governmental plan developed by M. Hausner, the deputy Prime Minister creates strong hopes for fulfilling the Maastricht criteria - mainly the public debt criterion - in the predictable future. As IMF indicated, the Hausner plan, fully implemented, would be a decisive step in reforming government finances.

At the same time traditional attributes of national sovereignty - money being one of them - are not presently the Poles' concern. Public opinion polls done in January 2002 disclosed that almost $96 \%$ of the Polish people knew that the euro was born; $63 \%$ were convinced that, one day, the euro should replace the Polish zloty, and $52 \%$ thought that it might be done in coincidence with EU membership. Despite the

5) The event took place on 5 December, 2002, just one week before the final accession talks that were held in Copenhagen between the Polish Prime Minister Leszek Miller and Anders Fogh Rasmussen, Prime Minister of Denmark (Gazeta Wyborcza, 6 December, 2002). 
fairly positive results of this poll and also that of October 2002 (see Graph 2), a question still remains for people in the streets: has the country to fulfil the dozen or so requirements in order to be a formal member of eurozone and benefit from the single currency? Thus, it is noteworthy in the Polish case that many arguments in favour of and against the euro are political rather than economic.

\section{Graph 2}

Support for the Euro in the Accession Countries

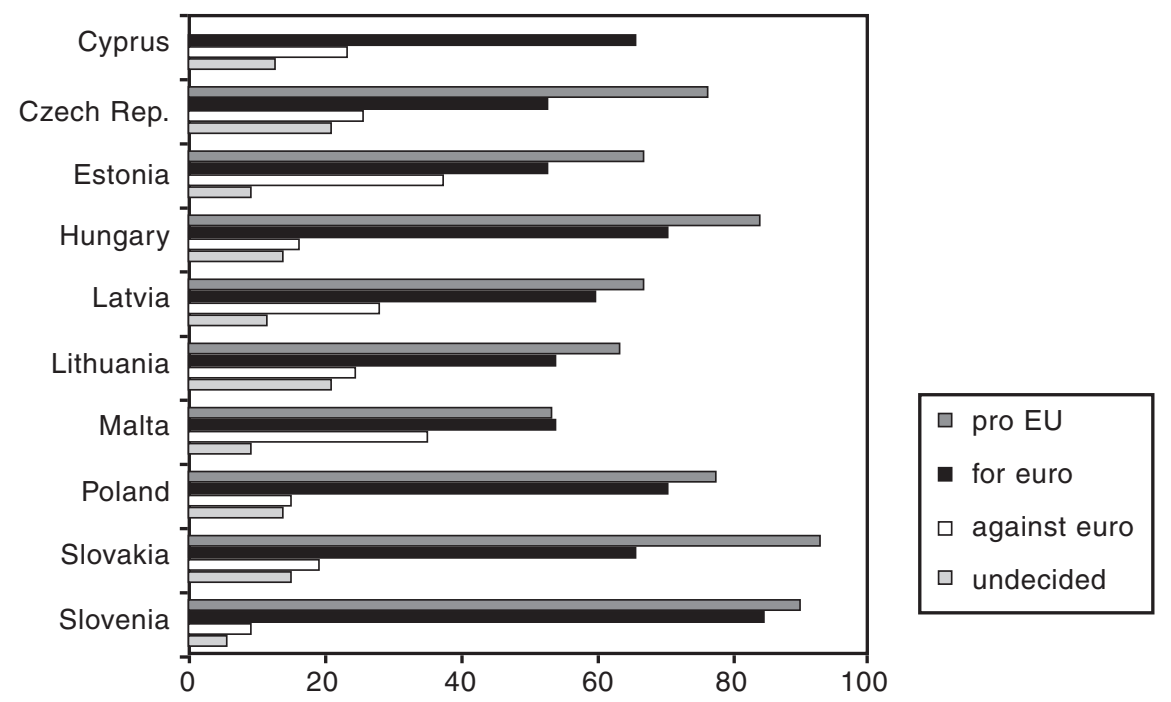

Note: Support for euro as measured in autumn 2002; The EU membership referenda took place, positively, between March and September 2003 except for Cyprus where no referendum was organised.

The euro and Czech perceptions of the European order. The same incertitude holds true for the Czech Republic. On the one hand, the Czech Republic made a series of steps of paramount sense for attracting foreign investments and for becoming an important centre for multinationals. This is also why the Social-Democratic government decided both to sell all large semi-state banks to strategic foreign investors and to harmonise much of the Czech legislation with the "acquis" (see Štěpán, 2001). The Social Democrats, active and unconditional supporters of the Accession, seem to share the opinion that the euro would be attractive for foreign companies seeking for the removal of exchange rate fluctuations and for the lowering of transaction costs. On the other hand, Czech opponents to the single currency, long supported by the new President Václav Klaus, argue that the euro threatens the Czech's independence (self-determination) and that the EMU may constrain Czech economic policy. Klaus expressed his sentiment toward the EU saying that he wishes his country "to remain a self-governing nation" (see Chattam House, 2001). Klaus and the Civic Democrats he represents, disapproved of any increase in EU competencies and deeper political integration (see Štěpán, 2001). For Klaus, who was Prime Minister in 1992 - 1997, the euro seems to be a complex economic issue where the fact that, "...Europe is not a natural currency area" (ibidem) still holds true. For him, this approach generates a situation in which "...the EMU costs exceed its benefits" and "...economically weaker regions will not be protected by 
changing currencies and not protected by appropriate interest rates...". However, the President's scepticism faces the certain optimism of public opinion, which in March 2003 displayed for the second time (see Eurobarometer, 2002) a $60 \%$ support for the euro.

Summing up, it is not clear at all what policy Václav Klaus, who cannot directly influence the central bank, will conduct. In its document on the euro accession strategy, published at the end of 2002. The Czech National Bank states that, "...the first possible year for joining the eurozone is 2007" (see CNB, 2002). But some economists predict that the personal political belief of President Klaus will become key for the new composition of the Monetary Board of the CNB, which will partially be reset at the beginning of 2004. In other words, the transparency of the Czech political scene may become under question (see The Economist, 2003).

The euro and Hungarian perceptions of the European order. Hungarians ${ }^{6)}$ strongly supported their membership in the EU during the April 2003 referendum. Not less than $84 \%$ of those who participated voted "yes" for the Union. Although the vote was clearly supportive of joining the EU, the $46 \%$ turnout was much lower than anticipated, and below the $60 \%$ expected by the government. The most likely explanation is voter apathy, disillusionment resulting from the results of the accession negotiations and growing tensions within the economy. Nevertheless, the outcome reflects a relatively high level of public confidence in the economic policy that has been maintained by the Hungarian authorities for a long time.

The growth performance of Hungary over the last few years suggests that it should withstand adverse external developments and it might continue with moderate, but stable development, even if the $\mathrm{EU}$ is in fact in stagnation. This also gave the government room for manoeuvre to shift toward an improvement of living standards, whilst the fulfilment of the convergence criteria becomes an unchanged target for the time-being. The key question is therefore: how long can Hungary counts on growth and export of this magnitude? As Zsigmond Járai (2003), Chairman of the Hungarian Central Bank, officially declared the intention to fulfil the Maastricht criteria as soon as possible. However, he warned that an unstable fiscal policy could move back from the government's $2007-2008$ target to a $2009-2010$ target. He strongly indicated that the huge public sector wage increase might threaten the low inflation goal. Analysts treated this statement as a hidden critique of the governmental fiscal policy that is supposed to be focusing on debt-shrinking this year. It is still uncertain whether these plans will be fulfilled. It brings out the fact that an early fulfilment of the convergence criteria by Hungary - a small economy in search of prosperity - might not be easy. If accomplished, the Hungarian workforce may appear to be loser in their rigid application.

At the same time, representatives of Hungarian enterprises, with a strong representation in Parliament and being a vehicle for the dynamic foreign-led export sector, consider that the euro may appear either in 2006 or in 2007 . Another economic argument for the quick adoption of the euro would fit the Hungarian attempt to be an important trade partner within the Union by establishing a leadership of Hungarian enterprises and by creating an international framework of the "Ten" Chambers of Economics and Trade. The most important claim of the enterprises is, however, that EU should decide on another "big bang" like EU-membership enlargement under the form of a once-and-for-all "euro-expansion".

6) I would like to express my thanks to Peter Akós Bod, Adviser to the President of Hungary, for his comments on this part. I also owe to the Economic-Commercial Department of the Embassy of Poland in Budapest special thanks fpr its support. 
To sum up, there are not many good economic or power-related arguments for Hungary with regard to the euro and its insistence on doing it according to the drafted schedule. The basic argument that explains this insistence is the conviction, shared by all Hungarian parties, that the euro - like EU membership - will become an important political instrument and not only an economic one.

\section{By Way of Conclusions}

Enlargement is now a reality. It was a long-term political project, which will not be fully completed unless accession countries start to use the euro. A large European Union will not be able to tackle its four major challenges: economic performance, internal cohesion, security and an external role - without being supported by the political movement and economic performance of the accession countries. No one doubts that the economies of the latter need to be strengthened. This may be achieved by the effective action of the EU to help CECs eliminate the distance between the level of economic development of the EU countries and that of new Member States.

The strength of the eurozone economy is based, however, on the acceptance of the set of rules ranging from the Maastricht criteria to the Stability and Growth Pact. The latter one has lost its credibility and needs to be modified for several reasons. The first one is the most obvious. Only a rule-based system can guarantee that commitments are enforced and that all Member States are treated equally. Secondly, unless the rules of the Pact are resolved, the negotiations on the participation of the new Member States in the eurozone will not go smoothly. The lack of proper rules risks undermining the credibility of the institutional framework and the confidence in sound public finances of the EU states across the eurozone. Moreover, the EU needs a proper fiscal co-ordination policy to catch-up with a right policy mix of budgetary and monetary policies. It is good per se to schedule a long-term economic development of the EU. Consequently, it may prove to be a good solution for the NMS and their catching-up policies, bearing in mind that they have to start to fulfil their the first convergence programs in 2004.

The desire to start using the euro as soon as possible is understandable. Participation in the eurozone will offer real benefits for the accession countries. They will be able to eliminate currency risk in their trade with the euro area and to reduce their transaction costs. And what is even more important, it will strengthen the position of their domestic players in the large and liquid EMU capital market and lower the credit costs for reliable borrowers, and especially for government debt. The fear raised by a quick adoption of the euro is understandable as well. The new Member States are aware that the will to adopt the euro radically alters their economic and fiscal policy environment. The Union should give them a chance to complete this process within the euro-system.

In such a context, the adoption of the euro will stand for the final phase of enlargement leading to a sweeping away of the effects of the past division of Europe. This needs a policy consensus, which is commonly noted as a key to the progress of European integration. It is precisely this issue, which refers to the current Union's struggles to define a Common Foreign and Security Policy and to play a more decisive role in maintaining peace in the world. Indeed, the latter idea becomes a staple of mainstream European integration. I would say however, following Monnet's remark (see Collignon, Schwarzer, 2002), that common money is of particular importance for the EU. Therefore the enlargement through-the-euro will strengthen both its moral authority - as a stable economic and monetary policy zone - and its institutional capacity to deal with crises, conflicts and other difficult problems in the 
twenty-first century. With the introduction of the euro, the EU is starting to play a larger international role. This will not work properly unless the every rules of the euro are observed by the every Member State, or unless the euro is introduced in the "Ten" new members. Otherwise, negative results would prevail for the affirmation of the euro as a global currency competing with the USD. The EU as a potential rival and champion of multilateral rules and institutions would not tie US down without the real single money. All this illustrates that the EMU and the euro should also be understood and analyzed as a political project and not only as an the economic one.

References

Balcerowicz, L. (2003), "EU Enlargment and Cathing-up". Warsaw, National Bank of Poland.

Barysch, K. (2003), "A Pact for Stability and Growth". Brussels, Centre for European Reform.

Berlin European Council, Conclusions, Agenda 2000.

Buti, M., Eijffinger, S., Franco, D. (2003), "Revisiting the Stability and Growth Pact: Grand Design or Internal Adjustment?" European Economy, Economic Papers.

Collignon, S., Schwarzer, D. (2002), "The Power of Ideas. The Contribution to the Euro of the AMUE". London, School of Economics, manuscript.

Copenhagen European Council Summit, Conclusions. December 1993.

CNB (2002), "The Czech Republic and the Euro - Draft Accession Strategy". Prague, Czech National Bank.

EBRD (2003), "Transition Report." London, European Bank for Reconstruction and Development.

Eurobarometer (2002). Brussels, European Commission. (2003). Brussels, European Commission.

European Economy, Enlargement Papers, "Economic Forecasts for the Candidate Countries, Spring 2003", 2003, No. 15.

European Economy, Autumn 2003 Economic Forecasts, No. 5/2003.

Gottfries, N. (2002), "Why is Sweden Not in EMU?" Current Sweden, Swedish Institute, Working Paper No. 435.

IMF (2003), "Poland, Concluding Statement of the IMF Staff Mission." Warsaw.

Klaus, V. (2001), "New Europe Seminar on the Future of the European Union". London, Chatham House.

Madrid European Council Summit, Conclusions. December 1995.

NBH (2003), " Quarterly Report on Inflation.” Budapest, National Bank of Hungary.

Nice European Council Summit, $2301^{\text {st }}$ Council meeting, 2000.

OECD (2003), "Economic Outlook". Paris, No. 74.

"Prickly Václav Klaus". The Economist, March 6, 2003.

Rostowski, J. (2003), "Economic Convergence and EMU Membership". Warsaw, National Bank of Poland.

(2003), "Europe Behind Us, Euro Before Us" (in Polish). Rzeczpospolita, 18 January.

Soros, G. (1993), "Prospect for European Disintegration". The Soros Foundation.

Štěpán, J. (2001), "The Czech Republic: Awaiting Elections and a Fiscal Reform", in The Stockholm Report on Transition, 11(3), pp. 7-17.

Temprano-Arroyo, H., Feldman, R. A. (1998), "Selected Transition and Mediterranean Countries: an Institutional Primer on EMU and EU Relations". Washington, IMF, Working Paper No. 82.

“The Euro at 25" (2002, 2003). London, Centre for European Policy Studies. 